p-ISSN. 2086-9029

e-ISSN. 2654-5675

Vol. 22 No. 2, HIm. 159-352, Desember 2020

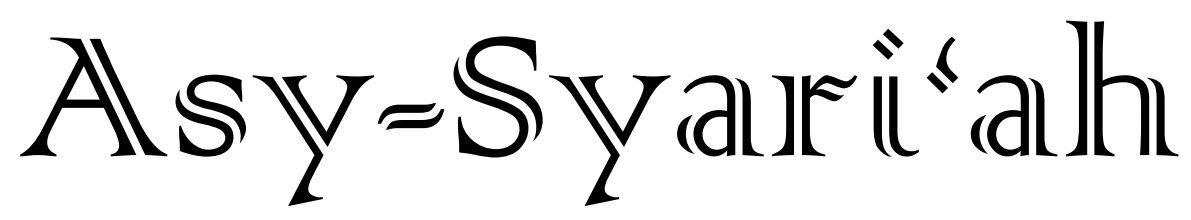

- Implementasi Prinsip Keadilan dalam Hukum Perjanjian Syari'ah

$(159-178)$ Zaenudin Mansyur

- Akad Rahn Tasyjili pada Gadai Tanah Pertanian di Pegadaian Syariah

$(179-196)$ Rahmadi Indra Tektona, Dyah Ochtorina Susanti

- Potensi Sertifikasi Halal dalam Mengahadapi Masyarakat Ekonomi

$(197-218)$ ASEAN

Deviana Yuanitasari, Helitha Noviana Dewi

- Akad Mudharabah sebagai Instrumen Pendanaan dan Pembiayaan di

$(219-236)$ Lembaga Keuangan Syariah

Asep Dadang Hidayat, Moh. Sar'an

- Praktik Rekayasa Dispensing Pump SPBU Persfektif Peraturan

$(237-258)$ Perundang-Undangan dan Hukum Islam

Hazar Kusmayanti, Ratu Chairunissa

- Dinamika Penerapan Akad Syariah dalam Produk Keuangan di Bank

$(259-274)$ Syariah

Jaenudin

- Etika Bisnis Islam pada Perilaku Pemasaran dan Kepuasan Konsumen

$(275-290)$ Wida Ramdania

- Kebijakan Fiskal Islam pada Masa Al-Khilafah Al-Islamiyah

Supriatna, Dedah Jubaedah

- Pelanggaran Prinsip Tanggungjawab Perusahaan Asuransi Investasi Persfektif Perundang-Undangan dan Hukum Ekonomi Syariah

Yoghi Arief Susanto, Yeti Sumiyati

- Identifikasi Kebutuhan Pembiayaan Syariah Peternak Lembu di Deli (337-352) Serdang

Marlya Fatira AK, Anriza Witi Nasution, Tuti Kurnia

FACULTY OF SHARIA AND LAW

STATE ISLAMIC UNIVERSITY SUNAN GUNUNG DJATI BANDUNG-INDONESIA IN COLLABORATION WITH ASOSIASI SARJANA SYARIAH INDONESIA 


\section{Asy-Syari'ah}

Volume 22, Number 2, 2020

\section{EDITOR-IN-CHIEF}

Ine Fauzia

\section{EDITORIAL BOARD}

Sofyan al-Hakim, UIN Sunan Gunung Djati Bandung, Indonesia Deni Kamaludin Yusup, UIN Sunan Gunung Djati Bandung, Indonesia

Meria Utama, Fakultas Hukum Univrsitas Sriwijaya, Indonesia

Dewi Mayaningsih, UIN Sunan Gunung Djati Bandung, Indonesia

Andrey Sujatmiko, Fakultas Hukum Universitas Trisakti, Jakarta, Indonesia

Hetty Hassanah, Universitas Komputer Indonesia, Indonesia

Tarun Ghawana, CDMS, New Delhi, India

Muhammad Hasanuddin, UIN Sunan Gunung Djati Bandung, Indonesia

Syahrul Anwar, UIN Sunan Gunung Djati Bandung, Indonesia

Aden Rosadi, UIN Sunan Gunung Djati Bandung, Indonesia

\section{PEER-REVIEWERS}

S. Salahudin Suyurno, Universiti Teknologi MARA (UiTM) Melaka, Malaysia

Ezani Yaakub, Universiti Teknologi MARA (UiTM) Malaysia, Malaysia

Zezen Zaenal Mutaqin, University of California, Los Angeles, United States

Muhammad Irfan Helmy, IAIN Salatiga, Semarang, Indonesia

Ahmad Ali Nurdin, UIN Sunan Gunung Djati Bandung

Tajul Arifin, UIN Sunan Gunun Djati Bandung, Indonesia

Mohamad Anton Athoillah, UIN Sunan Gunung Djati Bandung, Indonesia

Renny Supriyatni, Universitas Padjadjaran, Indonesia

Ahmad Tholabi Karlie, UIN Syarif Hidayatullah Jakarta, Indonesia

Ija Suntana, UIN Sunan Gunung Djati Bandung, Indonesia

Ahmad Fathonih, UIN Sunan Gunung Djati Bandung, Indonesia

Fauzan Ali Rasyid, UIN Sunan Gunung Djati Bandung, Indonesia

Rahman Syamsuddin, Universitas Islam Negeri Alauddin Makassar, Indonesia

\section{PROOFREADER/DESIGN COVER}

Nanang Sungkawa

\section{LAYOUT EDITOR}

Opik Rozikin

Asy-Syari'ah has been accredited by The Ministry of Education and Cultere, Republic of Indonesia as an academic journal in Sinta 3 (SK Diirjen Penguatan Riset dan Pengembangan Kemristekdikti No. 14/E/KPT/2019), valid for 5 years from Volume 19 No. 1 Tahun 2017 until Volume 23 No. 2 Tahun 2022. 


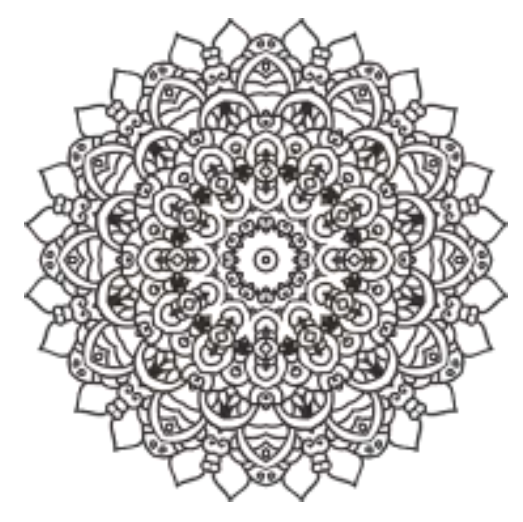

\title{
PRAKTIK REKAYASA DISPENSING PUMP SPBU PERSPEKTIF PERUNDANG-UNDANGAN DAN HUKUM ISLAM
}

\author{
${ }^{1}$ Hazar Kusmayanti, ${ }^{2}$ Ratu Chairunissa \\ ${ }^{12}$ Fakultas Hukum Universitas Padjadjaran \\ E-mail: hazar.kusmayanti@unpad.ac.id, ratuchairunissa@yahoo.co.id
}

\begin{abstract}
This research aims to examine and analyze the responsibilities of petrol stations as well as legal protection that can be obtained by consumers designed by petrol stations based on statutory views and Islamic law. This study uses the Normative Juridical method with references to Law Number 8 of 1999 concerning Consumer Protection and Law Number 2 of 1981 concerning Legal Metrology regarding measuring instruments. These results conclude that: First, engineering pump removal by business actors carried out by SPBU managers has an impact on the revocation of the PASTI PAS predicate by Pertamina which has harmed consumers, so that it is the responsibility of business actors who provide compensation by Article 19 of the Consumer Protection Law because it has increased to default. Furthermore, in Islamic law, the stipulation of compensation is carried out because no loss or damage to the victim has occurred. Second, legal protection for consumers, namely in the form of preventive and repressive. Preventive measures are carried out by guiding by the government and Pertamina, while repressiveness is carried out by law enforcement and / consumer dispute resolution both through courts and outside the court. Likewise, the Islamic view of pump engineering is not in line with the principles and principles of Islamic law because there is an element of gharar in it.
\end{abstract}

Keywords: Engineering Dispensing Pump; Business Actors; Consumers 
Abstrak: Penelitian ini bertujuan untuk mengkaji dan menganalisis mengenai tanggung jawab pelaku usaha SPBU serta perlindungan hukum yang dapat diperoleh konsumen terkait rekayasa dispensing pump oleh pelaku usaha SPBU berdasarkan pandangan perudang-undangan dan Hukum Islam. Penelitian ini menggunakan metode Yuridis Normatif dengan rujukan Undang-Undang Nomor 8 Tahun 1999 tentang Perlindungan Konsumen dan Undang-undang Nomor 2 Tahun 1981 tentang Metrologi Legal mengenai alat ukur. Hasil penelitian ini menyimpulkan bahwa: Pertama, rekayasa dispensing pump oleh pelaku usaha yang dilakukan oleh pengelola SPBU berdampak pada pencabutan predikat PASTI PAS oleh Pertamina dianggap telah merugikan konsumen, sehingga tanggung jawab pelaku usaha yaitu memberikan ganti rugi sesuai dengan Pasal 19 Undang-undang Perlindungan Konsumen karena telah berbuat wanprestasi. Selanjutnya dalam Hukum Islam penetapan ganti rugi dilakukan apabila unsur-unsur darar atau kerugian pada korban telah terjadi. Kedua, perlindungan hukum bagi konsumen yaitu dalam bentuk preventif dan represif. Preventif dilakukan dengan melakukan pembinaan oleh pemerintah dan Pertamina, sedangkan represif yaitu dengan adanya penegakan hukum dan/atau penyelesaian sengketa konsumen baik melalui pengadilan maupun di luar pengadilan. Begitu juga pandangan Islam mengenai rekayasa dispensing pump tidak sejalan dengan prinsip dan asas Hukum Islam karena terdapat unsur gharar di dalamnya.

Kata-Kata Kunci: Rekayasa Dispensing Pump; Pelaku Usaha; Konsumen 


\section{Pendahuluan}

Perlindungan konsumen masih relatif baru di Indonesia. Masih banyak kasus konsumen yang dirugikan sedangkan konsumen masih kesulitan untuk menuntut ganti rugi, bahkan konsumen terkesan sangat lemah kedudukannya di hadapan pelaku usaha. Karena, yang menjadi kebiasaan di Indonesia adalah asas "take it or leave it", konsumen di Indonesia hanya dijadikan objek aktivitas bisnis oleh para pelaku usaha. Seiring dengan kemajuan teknologi, seringkali konsumen tidak mengetahui apa yang telah diterapkan oleh para pelaku usaha dalam produknya ${ }^{1}$. Meningkatnya dominasi pelaku usaha terhadap konsumen dengan penguasaan produk yang sepenuhnya berada pada produsen, sehingga kegiatan usaha menjadi faktor penting diberlakukannya Undang-undang Nomor 8 Tahun 1999 tentang Perlindungan Konsumen yang disahkan pada tanggal 20 April 1999. Ini merupakan upaya pemerintah untuk memberikan jaminan perlindungan kepada kepentingan konsumen, baik selaku pengguna, pemanfaat maupun selaku pemakai barang dan/atau jasa yang ditawarkan oleh pelaku usaha².

Hukum ekonomi Islam telah mengatur perlindungan konsumen. Bahkan perlindungan konsumen dalam Islam suatu keharusan dan merupakan syarat mutlak untuk tercapainya suatu keberhasilan. Perlindungan dalam bahasa Arab sama artinya dengan "Asama" sedangkan konsumen dalam Bahasa Arab yaitu "mustahliku". Sebagaimana firman Allah SWT dalam Al-Quran, surah An-Nisa Ayat 29:

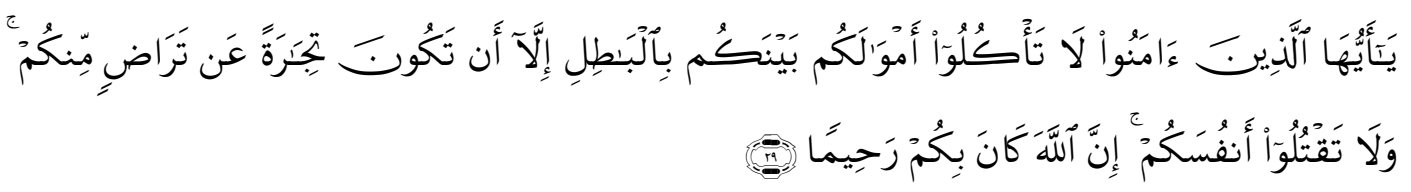

"Hai orang-orang yang beriman, janganlah kamu saling memakan harta sesamamu dengan jalan yang batil, kecuali dengan jalan perniagaan yang Berlaku dengan suka sama-suka di antara kamu. dan janganlah kamu membunuh dirimu. Sesungguhnya Allah adalah Maha Penyayang kepadamu".

Selanjutnya Rasulullah SAW mempertegas kembali melalui sabdanya: "Tidak boleh melakukan perbuatan yang memudharatkan dan tidak boleh membalas kemudharatan dengan cara yang salah". (HR. ibnu Majjah dan al-Daruqutni).

Hadits di atas menjelaskan bahwa sesama pihak yang berserikat hendaknya saling menjaga hak dan kewajiban masing-masing, sehingga tidak tejadinya kecurangan-kecurangan yang dapat mengakibatkan kerugian sebelah pihak yang melakukan perserikatan tersebut. Kecurangan banyak terjadi di masyarakat, seiring dengan perubahan ruang gerak masyarakat dan teknologi, salah satunya adalah dalam hal penggunaan Bahan Bakar

\footnotetext{
${ }^{1}$ Suyadi, Perlindungan Hukum Konsumen Produk Pangan Olahan yang Mengandung Bahan Rekayasa Genetik, Jurnal Dinamika Hukum Vol. 10 No. 1 Januari 2010, hlm. 70

${ }^{2}$ Yudha Hadian Nur dan Dwi Wahyuniarti Prabowo, Penerapan Prinsip Tanggung Jawab Mutlak Dalam Rangka Perlindungan Konsumen, Jurnal Litbang Perdagangan, Vol. 5 No. 2, Desember 2011, hlm. 177.
} 
Minyak (BBM) terus meningkat. Pemerintah pada awalnya mendirikan sebuah perusahaan minyak nasional yang dikenal dengan PT. Pertamina untuk mempermudah masyarakat dalam memperoleh BBM melalui Stasiun Pengisian Bahan Bakar Umum (SPBU). Tetapi dalam pelaksanaanya pelayanan pembelian di SPBU sering terjadi masalah antara pelaku usaha dan konsumen yang dapat menimbulkan kerugian terhadap konsumen.

Merekayasa sistem tekonolgi digital pengukur otomatis perhitungan aliran BBM (dispensing pump) melalui alat tambahan tombol switch on/off dan Prited Circuit Board (PCB) merupakan salah satu tindakan curang yang dilakukan oleh SPBU di Jalan Riau/RE. Martadinata dan Kiaracondong Kota Bandung. Hal ini menyebabkan tidak sesuainya takaran, timbangan dan jumlah BBM dalam hitungan menurut ukuran yang sebenarnya. Pelaku usaha cenderung fokus untuk mendapatkan keuntungan sebesar-besarnya tanpa memperhatikan konsumen sebagai objek keuntungan semata. Padahal sejatinya upaya pemberdayaan dan perlindungan konsumen telah diatur dalam Undang-Undang Nomor 8 Tahun 1999 tentang Perlindungan Konsumen dan mengenai alat ukur diatur dalam Undang-Undang Nomor 2 Tahun 1981 tentang Metrologi Legal.

Melihat fakta yang terjadi di lapangan, masih saja didapati praktik kecurangan yang dilakukan oleh pelaku usaha SPBU dengan merekayasa sistem teknologi digital pengukur otomatis perhitungan aliran BBM (dispensing pump) yang tidak sesuai takaran, timbangan dan jumlah dalam hitungan menurut ukuran yang sebenarnya. Lebih jelasnya lagi kasus ini bermula ketika Direktorat Perlindungan Konsumen dan Tertib Niaga Kementerian Perdagangan melakukan inspeksi mendadak (sidak) di 8 (delapan) SPBU Kota Bandung. Pada sidak yang telah dilakukan, ditemukan adanya alat tambahan pada pompa ukur bahan bakar minyak berupa rangkaian elektronik atau Prited Circuit Board (PCB) di salah satu SPBU. Dua mesin SPBU tersebut berada di jalan Riau/RE. Martadinata dan Kiaracondong. Setelah dilakukan pengujian terhadap pompa ukur BBM, hasilnya melebihi batas kesalahan yang diizinkan yaitu sekitar 0,5 persen (100 mililiter) dari setiap 20 liter yang dikeluarkan ${ }^{3}$. Hal ini tentu sangat merugikan masyarakat yang secara sadar menyadari atau tidak sama sekali (tidak tahu) dilihat dari hak-hak konsumen yang harus dilindungi.

Melihat paparan kasus di atas, maka perlu diperhatikan lagi bahwa konsumen selaku pihak yang dilindungi harus mengenal dan mengetahui siapa saja orang-orang yang dapat dimintai pertanggungjawaban atas kerugian yang dialami oleh konsumen. Jika dilihat dari nilai keadilan kepada konsumen seharusnya pelaku usaha juga dimintai pertanggungjawaban materi atas nilai kerugian yang konsumen alami selain sanksi pidana dan sanksi administratif. Kecurangan melalui dispensing pump juga diatur di dalam Undang-undang Nomor 2 Tahun 1981 tentang Metrologi Legal yang merupakan ketentuan yang ditujukan untuk menjamin kebutuhan masyarakat akan kebenaran atau ketetapan suatu alat ukur,

${ }^{3}$ http://jabar.tribunnews.com/2018/10/21/kecurangan-di-dua-spbu-di-bandung-manipulasi-displaymeteran-bensin-hingga-buat-konsumen-rugi di akses 5 Februari 2019 pukul 10:30 WIB. 
takar timbang dan perlengkapannya sehingga diharapkan dapat menghindari kemungkinan-kemungkinan kerugian yang timbul dari penggunaan alat-alat tersebut. Menetapkan hak-hak konsumen dalam suatu perundang-undangan tanpa dapat dipertahankan atau dituntut secara hukum pemenuhannya, tidaklah cukup karena hanya berfungsi sebagai huruf-huruf mati saja dan tidak bermanfaat bagi konsumen. Konsumen pada akhirnya berhak mendapatkan hak-hak lainnya sesuai dengan kedudukannya sebagai konsumen berdasarkan peraturan perundang-undangan yang berlaku ${ }^{4}$. Penelitian ini akan mengkaji perlindungan hukum terhadap konsumen terkait rekayasa dispensing pump oleh pelaku usaha SPBU di Kota Bandung perspektif Peraturan perundang-undangan dan hukum Islam.

\section{Metodologi}

Penelitian ini bertujuan untuk mengkaji dan menganalisis mengenai tanggung jawab pelaku usaha SPBU serta perlindungan hukum yang dapat diperolehkonsumen terkait rekayasa dispensing pump oleh pelaku usaha SPBU berdasarkan pandangan perudang-undangan dan Hukum Islam. Penelitian ini menggunakan metode Yuridis Normatif dengan rujukan Undang-Undang Nomor 8 Tahun 1999 tentang Perlindungan Konsumen dan Undang-undang Nomor 2 Tahun 1981 tentang Metrologi Legal mengenai alat ukur.

\section{Praktik Rekayasa Dispensing Pump SPBU Perspektif Perundang-Undangan dan Hukum Islam}

Penyelenggaraan metrologi legal merupakan salah satu instrumen perlindungan konsumen. Standar dan pengukuran yang menjadi obyek pengaturan metrologi legal misalnya dimaksudkan untuk memberikan perlindungan konsumen dalam menghadapi praktik yang tidak transparan dan sulit dicek oleh konsumen seperti dalam bidang (1) pengisian bahan bakar minyak (BBM), (2) penetapan tagihan telepon,(3) penjualan beras, (4) penetapan tagihan listrik, air dan gas ${ }^{5}$. Pernyataan ini dikemukakan oleh Jhon Brich A.R. pada tulisannya, Benefit of Legal Metrology for the Economy and Society, A Study for the International Committee of Legal Metrology.

"From its beginning measurement was recognised as a provider of objective information. However when used in trade transactions where the measurement process lacked transparency, and there was asymmetry of information between the trader providing the measurements and the trader accepting these measurements (usually the purchaser in retail transactions, the producer in farm produce

\footnotetext{
${ }^{4} J a n u s$ Sidabalok, Hukum Konsumen di Indonesia, Bandung: Citra Aditya Bakti, 2010.hlm 41-43.

${ }^{5}$ John Brich, A.R.,Benefit of Legal Metrology for the Economy and Society, A Study for the International Committee of Legal Metrology, International Committee of Legal Metrology, 2003, hal. 16-17
} 
transactions and the smaller business in commercial transactions) there was considerable scope for uncertainty, disputation, transaction costs and market inefficiency. (133, 134, 139). These transaction costs can result from concerns about the accuracy of the measurement e.g. short measure, and the consistency of the measurement e.g. paying more than other customers. Typical examples of trade measurement transactions that may lack transparency and are difficult to check are 1. Petroleum sales to service stations and motorists. 2. Billing of telephone calls. 3 . Sale of firewood 4. Sale of grain and rice by farmers based on moisture measurements. 5. Sale of alcohol where stamped glasses are not used 6. Utility measurements i.e. electricity, water and gas."

Pemerintah mempunyai tanggung jawab untuk menetapkan standar pengukuran yang akurat melalui instrumen metrologi legal. Kewenangan ini berada di tangan Presiden yang dapat didelegasikan kepada menteri untuk urusan pemerintahan pusat, kepada gubernur untuk urusan pemerintahan provinsi, dan kepada bupati dan wali kota untuk urusan pada tingkat kabupaten/kota. Pemerintah berupaya untuk menjamin kesehatan dan keselamatan konsumen dengan menetapkan standar produk sesuai dengan karakternya masing-masing ${ }^{6}$. Standar pengaturan ini dimaksudkan agar produk-produk yang disampaikan kepada konsumen dapat dijamin kualitasnya serta penyajiannya lebih aman, sehat, dan biaya yang murah ${ }^{7}$.

Islam telah memberikan aturan tentang masalah takaran dan timbangan. ${ }^{8}$ Dalam Alquran disebutkan secara tegas perintah untuk menyempurnakan takaran dan timbangan secara benar, perintah ini juga diimbangi dengan ancaman bagi orang yang melakukan kecurangan, sehingga setiap muslim harus menyempurnakan takaran dan timbangan secar adil dan sempurna. Hal ini ditegaskan oleh Allah SWT dalam Q.S. Al-An'am: 152.

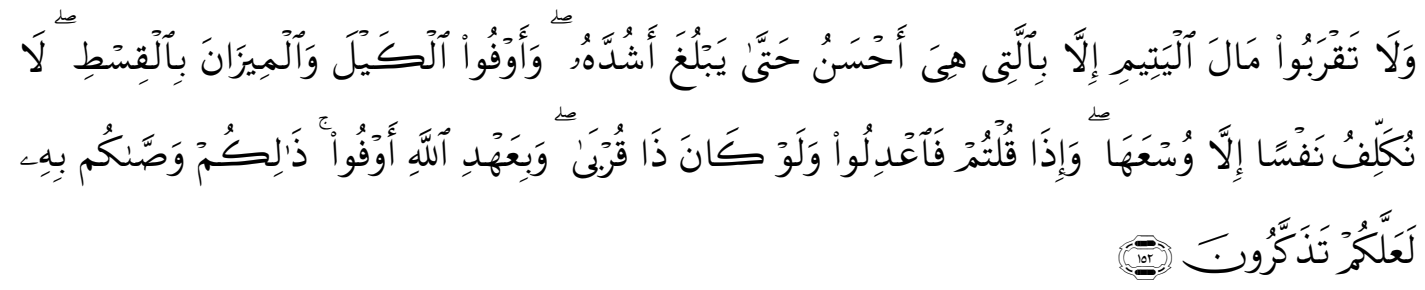

"dan janganlah kamu dekati harta anak yatim, kecuali dengan cara yang lebih bermanfaat, hingga sampai ia dewasa. dan sempurnakanlah takaran dan timbangan dengan adil. Kami tidak memikulkan beban kepada sesorang melainkan sekedar kesanggupannya. dan apabila kamu berkata, Maka hendaklah kamu

${ }^{6}$ Consumer International, The Decision Making in The Global Market,Trade,Standard, and Consumer, 2005, hlm. 111 (seperti dikutip dalam ${ }^{6}$ John Brich, A.R.,Benefit of Legal Metrology for the Economy and Society, A Study for the International Committee of Legal Metrology, International Committee of Legal Metrology, 2003, hlm. 16-17

IInternational Standard Organisation, The Consumer and Standard, Guidance and Principles for Consumer Participation in Standard Development, March, 2003., hlm. 4. (idem)

${ }^{8}$ Mahadir, Peranan Pemerintah dalam mengawasi Pasar Perspektif Ekonomi Islam, Jurnal As Salam 2 (1) 2018 , hlm $71-78$ 
Berlaku adil, Kendatipun ia adalah kerabat(mu), dan penuhilah janji Allah yang demikian itu diperintahkan Allah kepadamu agar kamu ingat."

Menyempurnakan takaran dan timbangan dalam ayat ini hukumnya wajib. Maka menyempurnakan takaran dan timbangan merupakan ketentuan yang wajib dipenuhi oleh setiap individu. Ketika Nabi datang ke Madinah, ia mendapati penduduk madinah curang dalam takaran dan timbangan, pada saat itulah Allah menurunkan ayat yang mengancam keras pelaku kecurangan dalam takaran dan timbangan. Ancaman ini terdapat dalam Q.S. Al-Muthaffifin: 1-3.

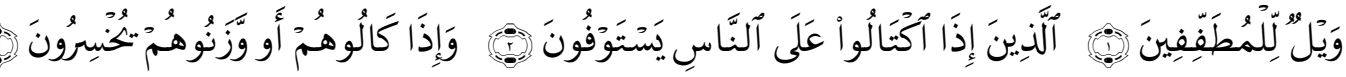

"kecelakaan besarlah bagi orang-orang yang curang, (yaitu) orang-orang yang apabila menerima takaran dari orang lain mereka minta dipenuhi, dan apabila mereka menakar atau menimbang untuk orang lain, mereka mengurangi."

Pandangan Islam dalam perdagangan merupakan aspek kehidupan yang dikelompokkan dalam muamalah, yakni yang berkenaan dengan hubungan yang bersifat horizontal dalam kehidupan manusia. Pada prinsipnya perdagangan merupakan suatu bentuk usaha yang dibolehkan menurut ajaran Islam. Meskipun demikian, sektor ini mendapatkan penekanan khusus dalam ekonomi Islam, karena keterkaitannya secara langsung dengan sektor riil. Dalam Islam, kegiatan perdagangan itu haruslah mengikuti kaidah-kaidah dan ketentuan yang telah ditetapkan oleh Allah SWT. Aktivitas perdagangan yang dilakukan sesuai dengan ketentuan-ketentuan yang digariskan oleh agama mempunyai nilai ibadah.

Dengan demikian, selain mendapatkan keuntungan materiil guna memenuhi kebutuhan ekonomi, praktik ini juga dapat mendekatkan diri kepada Allah SWT. Perdagangan yang dilakukan atas dasar prinsip kejujuran, yaitu didasarkan pada sistem nilai yang bersumber dari agama Islam dan aspek spiritual yang senantiasa melekat pada praktik pelaksanaannya, maka usaha perdagangan ini akan mendatangkan keuntungan kepada semua pihak yang terlibat. Tetapi perdagangan yang dilakukan dengan cara yang tidak jujur, mengandung unsur penipuan (gharar), maka akan ada pihak yang dirugikan, dan praktik lainnya yang sejenis jelas merupakan perbuatan yang dilarang dalam Islam. Dalam bahasa Arab, jujur merupakan terjemahan dari kata "shiddiq" yang artinya benar, dapat dipercaya. Dengan kata lain, jujur adalah perkataan dan perbuatan sesuai dengan kebenaran. Jujur adalah lawan kata dari kidzb (bohong atau dusta). Dengan demikian, jujur berarti keselarasan antara berita dengan kenyataan yang ada. Jadi, kalau suatu berita sesuai dengan keadaan yang ada, maka dikatakan benar atau jujur, tetapi kalau tidak, maka dikatakan dusta.

Sifat jujur merupakan sifat para Nabi dan Rasul yang diturunkan oleh Allah SWT dengan membawa cahaya penerang bagi umat di zamannya masing-masing. Nabi dan Rasul datang dengan metode (syariah) yang bermacam-macam, tetapi sama-sama 
menjunjung tinggi nilai-nilai kejujuran. Kejujuran tidak hanya pada ucapan, tetapi juga pada perbuatan. Sebagaimana seorang yang melakukan suatu perbuatan, tentu sesuai dengan yang ada pada batinnya. Seseorang yang berbuat "riya" tidaklah dikatakan sebagai orang yang jujur karena dia telah menampakkan sesuatu yang berbeda dengan apa yang dia sembunyikan (di dalam batinnya). Begitu pula orang munafik tidaklah dikatakan sebagai seorang yang jujur karena dia menampakkan dirinya sebagai seorang yang bertauhid, padahal sebaliknya. Jelasnya, kejujuran merupakan sifat seorang yang beriman, sedangkan lawannya dusta, merupakan sifat orang yang munafik. ${ }^{9}$

Kenyataan di masyarakat seringkali terjadi tindakan curang yang dilakukan oleh pelaku usaha dalam menjual barang jualannya, Pada tahun 2018, Direktorat Perlindungan Konsumen dan Tertib Niaga Kementerian Perdagangan melakukan inspeksi mendadak (sidak) terhadap dua mesin SPBU yang berada di jalan RE Martadinata dan Kiaracondong, Kota Bandung. Pada inspeksi tersebut, ditemukan adanya alat tambahan pada pompa ukur bahan bakar minyak berupa rangkaian elektronik (PCB). Hasil pengujian menunjukkan hasil yang melebihi batas kesalahan yang diizinkan yaitu sekitar 0,5 persen (100 mililiter) dari setiap 20 liter yang dikeluarkan ${ }^{10}$.

Sebagaimana yang diatur dalam Pasal 1365 KUHPerdata tindakan pelaku usaha SPBU tersebut dapat dikategorikan sebagai perbuatan melawan hukum jika memenuhi unsur-unsur sebagai berikut: ${ }^{11}$

\section{Ada Perbuatan}

Suatu perbuatan melawan hukum diawali oleh suatu perbuatan dari si pelakunya. Perbuatan disini dimaksudkan baik berbuat sesuatu (dalam arti aktif) maupun tidak berbuat sesuatu (dalam arti pasif). Berdasarkan hal ini pelaku usaha SPBU secara nyata telah berbuat sesuatu secara aktif yaitu dengan menambahkan alat tambahan tombol switch on/off dan PCB pada mesin dispensing pump SPBU.

\section{Perbuatan tersebut melawan hukum}

Perbuatan yang dilakukan oleh pelaku usaha SPBU tersebut hendaklah bertentangan dengan hukum. Tindakan rekayasa dispensing pump merupakan tindakan yang di larang dalam UUPK dan UU Metrologi Legal. Mendapatkan takaran BBM sesuai dengan nilai ataupun harga yang dibeli merupakan hak konsumen yang diatur di dalam Pasal 4 UUPK angka 3 yang menjelaskan bahwa konsumen memiliki hak atas informasi yang benar, jelas dan jujur mengenai kondisi jaminan barang dan/atau jasa namun pada

\footnotetext{
${ }^{9}$ Muhammad Nizar, Prinsip Kejujuran dalam perdagangan Versi Islam, Jurnal Istiqro : Jurnal Hukum Islam, Ekonomi dan Bisnis Vol.4 / No.1: 94-102, Januari 2018, ISSN : 2599-3348 (online) ISSN : 2460-0083 (cetak) hlm. 94

${ }^{10} \mathrm{http}: / / j a b a r . t r i b u n n e w s . c o m / 2018 / 10 / 21 /$ kecurangan-di-dua-spbu-di-bandung-manipulasi-displaymeteran-bensin-hingga-buat-konsumen-rugi di akses 5 Februari 2019 pukul 10:30 WIB.

${ }^{11}$ Aulia Muthiah, Tanggung Jawab Pelaku Usaha kepada Konsemen tentang Keamanan Pangan dalam Perspektif Hukum Perlindungan Konsumen, Dialogia Juridicia, Jurnal Hukum Bisnis dan Investasi, Vol.1 (1), 05 Mei 2017, hlm. 10
} 
dasarnya pelaku usaha dengan sadar dan sengaja mengidahkan hak konsumen tersebut. Pelaku usaha juga dibebankan kewajiban sebagai konsekuensi dari hak konsumen yang tertuang melalui Pasal 7 UUPK angka 2 dan 3 bahwa pelaku usaha dalam melakukan kegiatan usaha harus memberikan informasi yang benar, jelas dan jujur mengenai kondisi barang dan/atau jasa serta memperlakukan atau melayani konsumen secara benar dan jujur serta tidak diskriminatif. Sehingga pada dasarnya pelaku usaha melanggar hak konsumen yang dijamin oleh hukum serta bertentangan dengan kewajiban hukum pelaku usaha itu sendiri.

\section{Adanya kesalahan dari pihak pelaku}

Kesalahan adalah perbuatan dan akibat-akibat yang dapat dipertanggungjawabkan kepada diri si pelaku. Pasal 1365 KUHperdata menyatakan kesalahan mencakup kesengajaan dan kelalaian. Pada dasarnya tindakan rekayasa SPBU tersebut merupakan bentuk kesengajaan dimana pelaku usaha memiliki kesadaran dan mengetahui konsekuensi atas perbuatannya akan merugikan konsumen.

\section{Ada kerugian}

Kerugian yang ditimbulkan dari tindakan rekayasa dispensing pump ini berupa kerugian materil yaitu hilangnya keuntungan bagi konsumen terhadap kurangnya jumlah BBM yang seharusnya di dapatkan.

\section{Adanya hubungan kausal antara perbuatan dan kerugian}

Hubungan kausal antara perbuatan yang dilakukan dengan kerugian yang terjadi juga merupakan syarat dari suatu perbuatan melawan hukum. Pada kasus ini telah ditemukan hubungan sebab akibat secara faktual (causation in fact) yaitu telah ditemukannya alat tambahan tombol switch on/off dan PCB di dalam mesin dispensing pump tersebut.

Pada dasarnya sistem standarisasi takaran pada mesin SPBU sudah dilakukan baik dari pihak intansi metrologi, Pertamina Retail, maupun pihak SPBU sesuai dengan Undang-Undang Metrologi Legal bahwa setiap alat ukur wajib ditera ulang. Tera ulang pompa ukur BBM yang keluar dari nozzle adalah sebuah prosedur wajib bagi setiap SPBU karena hal ini berkaitan dengan kepentingan konsumen untuk memperoleh jumlah volume BBM sesuai dengan yang dibayar. Setelah dilakukan tera ulang setiap pompa ukur BBM wajib dilakukan suatu pengawasan untuk menjamin kebenaran pengukuran guna tercapainya tertib ukur. Instansi metrologi melakukan pengecekan yang dilakukan setiap 4 bulan sekali dimana dalam aturan yang di tentukan, ketika takaran BBM tersebut masih dalam toleransi 0,5 sesuai dengan Keputusan Menteri Perindustrian dan Perdagangan Nomor 251/MPP/Kep/6/9 maka masih di anggap sah ${ }^{12}$. Hasil pemeriksaan kedua mesin dispensing pump BBM SPBU Riau/RE. Martadinata dan Kiaracondong melebihi batas

\footnotetext{
23 Juli 2019.
}

${ }^{12}$ Hasil Wawancara dengan Wawuhan Dagis, Marketing di PT. Pertamina Retail Jakarta pada tanggal 
kesalahan yang berlaku yaitu hampir 2 kali lipat dari batas toleransi yang berikan. Pasal 27 Undang-Undang Metrologi Legal ayat (1) menyebutkan bahwa adanya larangan memasang alat ukur, alat petunjuk atau alat lainnya sebagai tambahan alat-alat ukur, takar atau timbangan yang sudah ditera atau yang sudah ditera ulang.

Perlindungan konsumen melalui Pasal 30 Undang-Undang Metrologi Legal menyatakan terdapat larangan oleh pelaku usaha berupa memproduksi dan/atau memperdagangkan barang dan/atau jasa yang tidak memenuhi atau tidak sesuai dengan standar yang dipersyaratkan dan ketentuan peraturan perundang-undangan; tidak sesuai dengan berat bersih, isi bersih atau netto, dan jumlah dalam hitungan sebagaimana yang dinyatakan dalam label atau etiket barang tersebut; tidak sesuai dengan ukuran, takaran, timbangan dan jumlah dalam hitungan menurut ukuran yang sebenarnya. Pasal 8 huruf (c) Undang-Undang Perlindungan Konsumen menegaskan bahwa pelaku usaha di larang memproduksi dan/atau memperdagangkan barang dan/atau jasa yang tidak sesuai dengan ukuran, takaran, timbangan dan jumlah dalam hitungan menurut yang sebenarnya. Penekanan pada Undang-Undang ini adalah pemilik SPBU yang bersangkutan, tetapi dalam konteks umum pelaku usaha juga tak terpisahkan dari Pertamina sebagai pemasok BBM kepada mitranya. Pertamina selaku pemegang izin usaha niaga BBM tetap melakukan upaya terhadap kelayakan SPBU apakah sesuai dengan program Pertamina setiap bulannya.

Berdasarkan Pasal 24 Undang-Undang Perlindungan Konsumen ayat (1) menyebutkan bahwa pelaku usaha yang menjual barang dan atau jasa kepada pelaku usaha lain akan tetap bertanggung jawab atas tuntutan ganti kerugian dan/atau gugatan konsumen sekalipun tidak memiliki hubungan kontraktual dengan konsumen yang bersangkutan. Tanggung jawab yang dimaksud dalam pasal ini adalah tanggung jawab berdasarkan perbuatan melanggar hukum. Dasar pertanggungjawaban ini terutama karena adanya syarat yang ditentukan di dalam pasal tersebut, yaitu apabila pelaku usaha lain yang menjual barang dan/atau jasa hasil produksinya kepada konsumen tidak melakukan perubahan apa pun atas barang dan/atau jasa tersebut, atau apabila pelaku usaha lain yang melakukan transaksi jual beli dengan pelaku usaha pihak pertama, tidak mengetahui adanya perubahan barang dan/atau jasa yang dilakukan oleh pelaku usaha pertama, atau pelaku usaha pertama yang bersangkutan telah memproduksi barang dan/atau jasa yang tidak sesuai dengan contoh, mutu, dan komposisi yang diperjanjikan sebelumnya. Pertamina tidak memenuhi ketentuan pertanggungjawaban berdasarkan pasal ini sehingga dalam Pasal 24 ayat (2) Undang-Undang Perlindungan Konsumen menjelaskan mengenai pengaturan pembebasan tanggung jawab. Pelaku usaha lain yang membeli barang dan/atau jasa dari pelaku usaha utama menjual kembali setelah melakukan perubahan atas barang dan/atau jasa tersebut maka pelaku usaha pertama dibebaskan dari tanggung jawab atas tuntutan ganti kerugian dan/atau gugatan konsumen. 
Terhadap tindakan curang pelaku usaha SPBU tersebut, meskipun Pertamina tidak bertanggungjawab secara hukum atas praktik pengurangan takaran, Pertamina tetap bertanggungjawab secara etis agar tidak menimbulkan efek negatif pada citra dan nama baik merek dagang Pertamina. Pertamina dalam upayanya memberikan tindakan pencabutan predikat PASTI PAS yang di miliki SPBU bersangkutan dalam kurun waktu dua bulan. Predikat ini dapat dimiliki kembali jika SPBU tersebut memperbaiki kekurangannya. Pertamina dalam hal ini hanya menyegel dispensing pump yang bermasalah sehingga operasi SPBU tetap jalan seperti biasa. Pertamina selanjutnya akan melakukan pemutusan hubungan kerja jika pelaku usaha dianggap telah merugikan banyak konsumen dan tidak melakukan perbaikan ${ }^{13}$. Sedangkan dari sisi regulasi yang ada di Pertamina untuk ganti rugi yang melibatkan oknum curang yang sampai dibawa ke ranah hukum, pihak Pertamina belum memiliki aturan khusus terkait mekanisme ganti rugi kepada konsumen yang pada umumnya konsumennya banyak dan sulit diidentifikasi.

Kerugian dapat diartikan berkurangnya harta kekayaan pihak yang satu yang disebabkan oleh perbuatan melanggar hukum oleh pihak yang lain ${ }^{14}$. Terdapat beberapa tujuan utama pertanggungjawaban pelaku usaha yakni pemberian kompesansi ganti kerugian, peyebaran resiko dan pencegahan ${ }^{15}$. Ganti kerugian dalam Undang-Undang Perlindungan Konsumen hanya meliputi pengembalian uang atau penggantian barang dan/atau jasa yang sejenis atau setara nilainya, atau perawaran kesehatan dan/atau pemnerian santunan yang sesuai dengan peraturan perundang-undangan yang berlaku. Ini berarti bahwa ganti kerugian yang dianut dalam Undang-Undang Perlindungan Konsumen adalah ganti kerugian subjektif ${ }^{16}$. Undang-Undang Perlindungan Konsumen mengatur pertanggungjawaban pelaku usaha atas konsumen di dalam Pasal 19 ayat (1) dimana pelaku usaha bertanggung jawab memberikan ganti rugi atas tindakan yang menimbulkan kerugian atas barang yang di konsumsi atau di perdagangkan. Pasal 19 ayat (2) menjelaskan lebih lanjut bahwa ganti kerugian yang di maksud dapat berupa pengembalian uang atau penggantian barang dana atau jasa yang sejenis atau setara nilainya, atau perawatan kesehatan dana tau pemberian santunan.

Undang-Undang Perlindungan Konsumen mengadopsi sistem pertanggungjawaban pelaku usaha atas dasar kesalahan (liability base on fault), karena karakter dasar liability base on fault pada dasarnya adalah perbuatan melawan hukum. Selain itu UUPK juga mengadopsi sistem pembuktian terbalik ini sebagaimana ditegaskan dalam Pasal 19, 22, 23 dan 28 UUPK. Pasal 19 ayat (4) UUPK menjelaskan bahwa pelaku usaha dibebankan

\footnotetext{
${ }^{13}$ Hasil Wawancara dengan Muhammad Subhan, Marketing di PT. Pertamina Retail Jakarta pada tanggal 28 Juli 2019 Pukul 13:56 WIB.

${ }^{14}$ Shidarta, Hukum Perlindungan Konsumen Indonesia, Edisi Revisi, Jakarta: Grasindo, 2004, hlm 133

${ }^{15}$ Celina Tri Siwi Kristiyanti, Hukum Perlindungan Konsumen, Jakarta: Cetakan Ketiga, Sinar Grafika Offset, 2011, hlm 22.

${ }^{16}$ Ahmadi Miru dan Sutarman Yodo, Hukum Perlindungan Konsumen Edisi Revisi, Jakarta: PT. RajaGrafindo Persada, 2015, hlm 136.
} 
asas praduga bersalah (presumption of liability) sehingga menganut asas pembuktian terbalik bagi pelaku usaha untuk membantah praduga yang dibebankan kepadanya sehingga tidak menjadi kewajiban konsumen untuk membuktikan kerugian yang dideritanya. Dalam prinsip beban pembuktian terbalik, tergugat dianggap bertanggung jawab sampai yang bersangkutan dapat membuktikan ia tidak bersalah, hal ini tentu bertentangan dengan asas hukum praduga tidak bersalah yang lazim dikenal dalam hukum namun jika diterapkan dalam kasus konsumen akan tampak asas ini cukup relevan karena yang berkewajiban untuk membuktikan kesalahan itu ada di pelaku usaha.

Sebagaimana konsekuensi dari prinsip ini, maka Pasal 19 ayat (3) Undang-Undang Perlindungan Konsumen menerapkan batas waktu pembayaran ganti kerugian 7 (tujuh) hari setelah transaksi. Batas waktu 7 (tujuh) hari tidak dimaksudkan untuk menjalani proses pembuktian tetapi hanya memberikan kesempatan kepada pelaku usaha untuk membayar atau mencari solusi lain. Dalam Pasal 23 Bab VI Undang-Undang Perlindungan Konsumen juga mengatur tentang akibat hukum jika pelaku usaha tidak bertanggung jawab atas kerugian konsumen. Pelaku usaha yang menolak dan/atau tidak memberi tanggapan dan/atau tidak memenuhi ganti rugi atas tuntuan konsumen sebagaimana dimaksud dalam Pasal 19 ayat (1), ayat (2), ayat (3), dan ayat (4) dapat di gugat melaui BPSK atau mengajukan ke badan peradilan di tempat kedudukan konsumen.

Hukum Islam memiliki ketentuan yang mendasar dalam masalah perikatan dan perjanjian yaitu dengan memberi kebebasan kepada pihak-pihak yang terlibat untuk mengambil bentuk dari macam-macam akad yang dipilihnya. Untuk ini segala macam cara yang menunjukkan adanya ijab dan qabul sudah dapat dianggap akad, dan akad ini memiliki pengaruh selama diselenggarakan oleh mereka dan memenuhi persyaratan penyelenggaraannya. Ketentuan inilah yang merupakan pokok-pokok syariat Islam yaitu suatu kaidah bahwa,akad-akad dapat dengan cara apa saja baik berupa perkataan maupun perbuatan yang menunjukkan maksud akad-akad tersebut ${ }^{17}$

Nabi Muhammad SAW bersabda: "Dua orang yang berjual beli berhak khiyar (tawarmenawar) selagi belum berpisah, maka jika mereka berlaku jujur dan berterus terang, diberkahkanlah mereka dalam jual belinya, tetapi jika berbohong dan tidak berterus terang, dihapuskanlah berkah jual beli mereka". Maksud yang terkandung dalam hadis tersebut antara lain melarang praktik jual beli yang bercacat karena tidak jujur, cidera janji dan hal-hal lain yang dilarang karena yang demikian tidak memberikan suatu keuntungan melainkan kemadlaratan. Jika seorang melakukan yang demikian setelah dibuatnya suatu perjanjian, bisa dikatakan mereka telah melakukan wanprestasi, yaitu mereka tidak melakukan prestasi yang seharusnya dilakukan atau ada unsur lalai dalam prestasinya setelah dilakukannya suatu perjanjian atau akad. Kelalaian Hukum Islam dalam memenuhi

\footnotetext{
${ }^{17}$ Yuni Harlina, Hellen Lastfitriani, Kajian Hukum Islam Tentang Wanprestasi Pada Konsumen Yang Tidak Menerima Sertifikat Kepemilikan Pembelian Rumah, Jurnal Hukum Islam, Vol XVII No. 1 juni 2017 , hlm. 
kewajiban untuk memberikan hak orang lain tergolong perbuatan yang dilarang, dimana sebelumnya telah diketahui adanya suatu perjanjian di antara mereka, selanjutnya bagi mereka yang melakukan pelanggaran/cidera janji karena tidak melakukan prestasinya. Maka, dikenakan sanksi kepadanya berupa pembayaran ganti rugi kepada pihak kreditur, dan atau penahanan yang menjadi hak miliknya sebagai suatu jaminan dari sejumlah yang dijanjikannya.

Menurut Syamsul Anwar, penyebab ganti rugi yang berkaitan dengan hukum Islam disebabkan beberapa faktor. Ada beberapa faktor yang dapat dijadikan sebagai sebab adanya ganti rugi, yaitu sebagai berikut ${ }^{18}: 1$ ) debitur tidak melaksanakannya akad ; 2) debitur alpa dalam melaksanakan akad, baik kesalahan disengaja atau kesalahan karena kelalaiannya.

Dalam Ilmu Fiqh, kesalahan disebut dengan at-ta"addi, yakni suatu sikap yang bertentangan dengan kewajiban dan hak yang tidak diizinkan oleh syara'. Terkait wanprestasi pelaku usaha SPBU karena merekayasa Dispensing Pump, Menurut Asmuni Mth dalam tulisannya teori Ganti Rugi (Daman) dalam bukunya yang berjudul Perspektif Hukum Islam penetapan ganti rugi unsur-unsur yang paling penting adalah darar atau kerugian pada korban. Adapun untuk mengukur daman atau ganti rugi dilihat baik dari kualitas maupun kuantitas sepadan dengan darar (kerugian) yang diderita oleh korban, walaupun dalam kasus-kasus tertentu pelipatgandaan ganti rugi dapat dilakukan sesuai dengan kondisi pelaku ${ }^{19}$.

\section{Perlindungan Hukum terhadap Konsumen Terkait Rekayasa Dispensing Pump Oleh Pelaku Usaha SPBU di Kota Bandung}

Perlindungan hukum dapat diartikan sebagai perlindungan oleh hukum atau perlindungan dengan menggunakan pranata dan sarana hukum ${ }^{20}$. Berkaitan dengan perlindungan hukum Satjipto Rahardjo berpendapat bahwa perlindungan hukum dilakukan untuk penegakan hukum demi mendapatkan kepastian hukum akan tetapi juga untuk mendatangkan kemanfaatan sosial dan keadilan agar masyarakat dapat menikmati semua hak-hak yang diberikan oleh hukum ${ }^{21}$. Perlindungan hukum merupakan bentuk perlindungan yang utama karena berdasarkan pemikiran bahwa hukum sebagai sarana yang dapat mengakomodasi kepentingan dan hak konsumen secara komprehensif, disamping itu

\footnotetext{
${ }^{18}$ Yusuf Al-Qardhawi, Bunga Bank Haram, Jakarta: Akbar Media Eka Sarana, 2003, hlm. 59

${ }^{19}$ A Rahmad Asmuni, Ilmu Fiqh 3, Jakarta: Direktorat Pemberdayaan Wakaf Direktorat jendral Bimbingan Masyarakat Islam, 2007, hlm. 120-123.

${ }^{20}$ Wahyu Sasongko, Ketentuan-Ketentuan Pokok Hukum Perlindungan Konsumen, Bandar Lampung: Penerbit Universitas Lampung, 2007, hlm 31.

${ }^{21}$ Tonny Rompis, Kajian Sosiologi hukum tentang Menurunnya Kepercayaan Masyarakat terhadap hukum dan Aparat Penegak Hukum di Sulawesi Utara, Lex Crimen Vol. IV/ No. 8 Oktober 2015 hlm. 53.
} 
hukum juga memiliki kekuatan memaksa yang diakui sehingga dapat dilaksanakan secara permanen $^{22}$.

Prinsip perlindungan hukum bagi rakyat Indonesia di bidang konsumen terkait dengan jaminan kepastian hukum (legal certainity):

"Product liability law is a legal instrument that is intended to provide guarantees to the rights of consumers, especially to the right to safety, health and the right to compensation. This instrument is needed because the regulation in the field of production (quality control techniques) and trade in goods is not sufficient to prevent or avoid and protect consumers who suffer losses, both losses in the form of defects or damage to the consumer's body (bodily / personal injury)." ${ }^{23}$

Pasal 1 angka (1) Undang-Undang Perlindungan Konsumen menyebutkan bahwa perlindungan konsumen merupakan segala upaya yang menjamin adanya kepastian hukum untuk memberikan perlindungan kepada konsumen. Perlindungan hukum pada dasarnya merupakan pemenuhan atas hak-hak konsumen yang seharusnya diberikan kepada konsumen, sehingga perlindungan konsumen sesungguhnya identik dengan perlindungan hukum yang terhadap hak-hak konsumen ${ }^{24}$.

Menurut Philip Kotler, pengertian konsumen adalah semua individu dan rumah tangga yang membeli atau memperoleh barang atau jasa untuk di konsumsi pribadi. Menurut Aziz Nasution, konsumen pada umumnya adalah setiap orang yang mendapatkan barang atau jasa digunakan untuk tujuan tertentu ${ }^{25}$. Sedangkan Sengketa terjadi apabila terdapat perbedaan pandangan atau pendapat antara para pihak tertentu tentang hal tertentu. Satu pihak merasa dirugikan hak-haknya oleh pihak yang lain, sedang yang lain tidak merasa demikian. Oleh karena itu sengketa konsumen merupakan sengketa antara konsumen dengan pelaku usaha (publik atau privat) tentang produk konsumen, barang dan/atau jasa konsumen tertentu. Beberapa hal yang perlu dijelaskan: pertama, pihak konsumen yang bersengketa itu haruslah konsumen dimaksud dalam Undangundang Perlindungan Konsumen, yaitu pemakai, pengguna dan/atau pemanfaat keluarga atau rumah tangganya dan tidak untuk tujuan komersial. Kedua, produk yang disengketakan haruslah produk konsumen, artinya produk itu merupakan barang dan/atau jasa yang umumnya dipakai, digunakan atau dimanfaatkan bagi memenuhi kepentingan diri, keluarga dan/atau rumah tangga konsumen ${ }^{26}$.

\footnotetext{
${ }^{22}$ Wahyu Sasongko, Op. Cit, hlm. 30

${ }^{23}$ Frank Zaid, "The Emerging Law on Product Liability and Consumer Product Warranties", Canadian Business Law Journal, 4, 1999. hlm 2.

${ }^{24}$ Shidarta, Op.Cit, hlm 19.

${ }^{25}$ Sutrisni, Moh. Zainol Arief, Pelayanan Pengisian BBM yang tidak memuaskan Di Lingkup Sumenep, Jurnal Jendela Hukum. Volume I Nomor 2 September 2014, hlm. 5

${ }^{26}$ Maslihati Nur Hidayati, "Analisis tentang alternatif penyelesaian sangketa perlindungan konsumen: Studi tentang efektifitas adan penyelesaian sangketa perlindungan konsumen", Lex jurnalica, vol 5 no 3 , Agustus 2008, hlm 171.
} 
Sarana perlindungan hukum ada dua bentuk, yaitu sarana perlindungan hukum preventif dan represif. Perlindungan hukum preventif dalam perlindungan konsumen yaitu berupa pembinaan dan kebijakan melalui aturan dan undang-undang. Perlindungan hukum bagi konsumen SPBU di dasarkan Undang-Undang Perlindungan Konsumen dan Undang-Undang Metrologi Legal. Pemerintah bertanggung jawab atas pembinaan penyelenggaraan perlindungan konsumen yang menjamin diperolehnya hak konsumen dan pelaku usaha sesuai dengan Pasal 29 Undang-undang Perlindungan Konsumen. Pada dasarnya konsumen masih banyak yang tidak mengetahui bahwa ada Undang-undang yang mengatur dan melindungi mengenai hak mereka. Ketentuan pada Pasal zo UndangUndang Perlindungan Konsumen menjanjikan upaya perlindungan konsumen melalui pemberdayaan melalui Lembaga atau intansi Perlindungan Konsumen yaitu Badan Perlindungan Konsumen Nasional (BPKN), Lembaga Perlindungan Konsumen Swadaya Masyarakat (LPKSM), Yayasan Lembaga Konsumen Indonesia (YKLI), dan BPSK. Dengan keberadaan lembaga/instansi ini dapat memberikan angin segar kepada para konsumen karena hak-hak mereka telah dilindungi oleh pemerintah dan mempunyai lembaga yang memberikan sosialisasi serta menampung keluhan-keluhan konsumen.

Penyadaran atas perlindungan hukum terhadap konsumen juga sebaiknya harus disadari oleh pelaku usaha. Irawan selaku Pengawas SPBU Riau/RE. Martadinata mengatakan bahwa dirinya sendiri mengetahui apa itu Undang-Undang Perlindungan Konsumen, dan konsumen yang datang ke SPBU memiliki hak dan kewajiban yang dilindungi oleh UUPK. Setiap penerimaan karyawan baru, Irawan mengatakan bahwa selalu ada program training mengenai konsumen yang wajib di ikuti. Pernyataan Irawan tersebut cukup menjelaskan bahwasanya setiap pengelola maupun karyawan SPBU haruslah mengetahui mengenai hak-hak konsumen maupun perlindungan hukum terhadap konsumen dikarenakan mereka setiap harinya berhadapan langsung dengan konsumen ${ }^{27}$. Pertamina dalam mewujudkan perlindungan konsumen terhadap hak-hak konsumen memberlakukan program sendiri secara sukarela (voluntary) dalam perusahaannya. Pertamina membangun program Pertamina Way sebagai transformasi awal menuju langkah perbaikan citra negatif di mata masyarakat. Program ini lahir dari keinginan pertamina untuk memuaskan konsumen pengguna SPBU. Pertamina menunjukkan bahwa dari sekian fasilitas dan pelayanan yang tersedia di SPBU pertamina, hal yang paling banyak di inginkan oleh konsumen yaitu jaminan takaran dan mutu BBM yang dijual dan kualitas pelayanan yang di salurkan melalui program PASTI PAS di SPBU ${ }^{28}$. Program PASTI PAS menerapkan 3S-PAS yaitu Senyum-Salam-Sapa oleh petugas pengisi BBM serta PAS merupakan jaminan layanan operator saat melayani konsumen, yaitu pas takaran, pas

\footnotetext{
${ }^{27}$ Berdasarkan hasil Wawancara dengan Irawan Pengawas SPBU 34-40133 Riau Kota Bandung pada hari Kamis 11 Juli 2019

${ }^{28}$ Customer satisfaction is everything, Energia edisi September 2018, Coorporate communication sekretaris Perseroan, PT Pertamina, hlm 20.
} 
kembalian, dan pas layanan. Pada dasarnya Pertamina meletakkan papan pemberitauan yang tercantum hak konsumen yang berupa: a) Mendapatkan ${ }_{3} S$ (Senyum, Salam, Sapa); b) penunujakan angka o ( $\mathrm{Nol}$ ) sebelum pengisian BBM, dan c) Menerima bukti pembayaran bila di minta.

Papan pemberitahuan tersebut juga menjelaskan jika ada konsumen yang haknya tidak terpenuhi, maka dapat menghubungi penanggung jawab SBPU tersebut dan apabila keluhannya tidak teratasi, konsumen dapat menghubungi Call Centre resmi Pertamina yang disediakan. Perihal keselamatan dan kerahasiaan identitas pelapor, Pertamina akan menjamin dan melindungi. Sedangkan dari sisi regulasi yang ada di Pertamina untuk ganti rugi yang melibatkan pelaku usaha SPBU curang yang sampai dibawa ke ranah hukum, pihak Pertamina belum memiliki aturan khusus terkait mekanisme ganti rugi kepada konsumen yang yang pada umumnya konsumennya banyak dan sulit diidentifikasi. Staf Administrasi SPBU Kiaracondong Yati Mulyadi menyatakan, Perlindungan dari konsumen yang dapat dilakukan oleh pihak SPBU salah satunya dengan pengecekan alat ukur dispensing pump setiap hari sebelum beroperasi oleh pihak SPBU selanjutnya Badan Metrologi Legal juga melakukan kegiatan tera ulang terhadap mesin SPBU demi menjaga keakuratan takaran BBM yang diterima konsumen agar adanya jaminan ketepatan dalam kebenaran pengukuran serta adanya ketertiban dan kepastian hukum dalam pemakaian satuan ukur, standar satuan, metode pengukuran dan UTTP.

Perlindungan Represif berupa penegakan hukum melalui penyelesaian sangketa sebagaimana yang diatur di dalam Undang-Undang Perlindungan Konsumen Bab X tentang penyelesaian sangketa konsumen. Sengketa-sengketa yang terjadi membutuhkan upaya penyelesaian yang dapat memberikan solusi atau keuntungan di kedua belah pihak. Upaya penyelesaian sengketa adalah upaya atau cara mengajukan tuntutan hak secara individu atau kelompok untuk menjamin terpenuhinya hak-hak konsumen. Upaya-upaya penyelesaian sangketa dengan cara-cara yang terdapat dalam Pasal 45 menerangkan bahwa setiap konsumen yang dirugikan dapat menggugat pelaku usaha melalui lembaga yang bertugas menyelesaikan sangketa antara konsumen dan pelaku usaha atau melalui peradilan yang berada di lingkungan peradilan umum. Dari sekian banyak cara penyelesaian sengketa di luar pengadilan, Undang-Undang Perlindungan Konsumen hanya memperkenalkan tiga macam yaitu arbitrase, konsiliasi dan mediasi yang merupakan bentuk atau cara penyelesaian sengketa yang dibebankan menjadi tugas BPSK. Penyelesaian ini mempunyai dasar hukum yaitu terdapat dalam KUHPerdata Indonesia (Buku ke III, Pasal 1851-1854 tentang perdamaian/dading) dan kemudian dalam Pasal 45 ayat (2) jo Pasal 47 UUPK.

BPSK dalam menyelesaikan sengketanya tetap memeriksa sengketa berdasarkan hukum yang berlaku bukan melakukan perdamaian antara kedua belah pihak. Penyelesaian ini tidak menutup kemungkinan dilakukannya penyelesaian secara damai oleh pihak yang bersengketa terlebih dahulu. Pada umumnya dalam setiap proses penye- 
lesaian sengketa selalu diupayakan untuk diselesaikan secara damai. Yang dimaksud penyelesaian sengketa secara damai adalah penyelesaian yang dilakukan oleh kedua belah pihak yang bersengketa (pelaku usaha dan konsumen) tanpa melalui pengadilan atau BPSK dan tidak bertentangan dengan undang- undang. Hal ini berlaku dalam sangketa pada layanan pembelian BBM pada SPBU ini, biasanya pelaku usaha jika konsumen merasa pelayanan yang diberikan tidak sesuai jaminan, akan lebih dulu menawarkan solusi dengan mengadakan negosiasi dengan konsumen bahkan terkadang lebih dahulu memberikan kompensasi kepada konsumen. Ini dilakukan karena terakit reputasi yang dimiliki pelaku usaha dan pada akhirnya akan berpegaruh kepada penjualan.

Prinsip penyelesaian sengketa damai ini lebih ke mediasi, Prinsip mediasi adalah bersifat sukarela atau tunduk pada kesepakatan para pihak, pada bidang perdata, sederhana, tertutup dan rahasia, serta bersifat menengahi atau bersifat sebagai fasilitator. Mediator wajib menentukan jadwal pertemuan untuk penyelesaian proses mediasi. Apabila dianggap perlu, mediator bisa melakukan permediasian antara konsumen dan pelaku usaha secara terpisah (kaukus). Pengalaman dan kemampuan mediator diharapkan dapat mengefektifkan mediasi di antara para pihak yang bersengketa ${ }^{29}$.

Dalam praktiknya pelaku usaha seharusnya lebih mengedepankan penyelesaian sangketa secara damai. Namun jika penyelesaian sangketa secara damai tidak mencapai kesepakatan, maka konsumen dapat menyelesaikan melalui BPSK diawali dengan permohonan atau pengaduan, baik tertulis maupun tidak tertulis yang mana peristiwa tersebut telah merugikan konsumen. Untuk yang bisa menggugat hanyalah seorang konsumen atau ahli warisnya. Sedangkan pihak lain seperti pemerintah, kelompok konsumen, dan lembaga swadaya masyarakat hanya dapat mengajukan gugatannya ke pengadilan bukan ke BPSK, hal tersebut seperti yang dimaksud dalam Pasal 46 UUPK.

Penyelesaian sangketa konsumen melalui peradilan diatur dalam Pasal 48 UUPK yang hanya memungkinkan apabila kedua belah pihak belum memilih untuk melakukan upaya penyelesaian sangketa di luar pengadilan dan upaya untuk menyelesaikan sangketa diluar pengadilan, dinyatakan gagal atau tidak berhasil oleh salah satu pihak atau keduanya yang bersangketa. Sengketa-sengketa yang dapat diselesaikan diluar pengadilan sifatnya terbatas.

Maksudnya, hanya dapat dipergunakan untuk bidang hukum tertentu, yakni di bidang keperdataan, hal ini disebabkan oleh sifat dari hukum perdata itu sendiri, yakni menyangkut hubungan hukum antara manusia yang satu dan manusia yang lainnya sehingga tidak terdapat unsur publik. Merujuk pada Pasal 46 ayat (1) UUPK, bentuk gugatan yang dapat dilakukan melalui pengadilan terdiri atas 4 jenis yaitu konsumen atau ahli waris yang bersangkutan, sekelompok konsumen yang mempunyai kepentingan yang

\footnotetext{
${ }^{29}$ Arif Rahman, Penyelesaian Sengketa Konsumen Melalui BPSK Kota Serang, Jurnal Hukum Vol 2 No 1 Juni 2018 , hlm 35 .
} 
sama, lembaga perlindungan konsumen swadaya masyarakat yang memenuhi syarat, yaitu berbentuk badan hukum atau yayasan yang dalam anggaran dasarnya menyebutkan dengan tegas bahwa tujuan didirikan organisasi tersebut adalah untuk kepentingan perlindungan konsumen dan telah melaksanakan kegiatan sesuai dengan anggaran dasarnya, serta pemerintah dan/atau intansi terkait apabila barang dan/atau jasa yang dikonsumsi atau dimanfaatkan mengakibatkan kerugian materi yang besar dan/atau korban yang tidak sedikit.

Mencurangi takaran BBM adalah suatu perbuatan yang tidak dapat dibuktikan langsung secara kasat mata tanpa adanya bantuan alat, yaitu bejana ukur sebagaimana standar yang ditentukan oleh Badan Metrologi. Sesuai dengan Pasal 6o Undang-Undang Perlindungan Konsumen pelaku usaha dapat dikenai sanksi-sanksi administrasi ganti rugi sebesar Rp.200.000.000,00 (Dua ratus juta rupiah). Namun masih terdapat kendala karena ketentuan yang menyatakan bahwa putusan BPSK bersifat final dan mengikat yaitu Pasal 54 ayat (3) Undang-Undang Perlindungan Konsumen, bertentangan dengan yang diatur di dalam Pasal 56 ayat (2) Undang-Undang Perlindungan Konsumen yang memberikan kesempatan kepada para pihak yang bersangketa untuk mengajukan keberatan atas keputusan BPSK yang telah diterima kepada pengadilan negeri paling lambat 14 hari kerja setelah menerima pemberitahuan putusan tersebut. Terhadap kasus pengurangan takaran BBM, yang diakibatkan oleh kecurangan pelaku usaha, delik yang memungkinkan untuk diterapkan adalah delik perlindungan konsumen yang diatur dalam Undang-Undang Perlindungan Konsumen dan delik terkait pelanggaran ketentuan UU Metrologi Legal. Melihat dari sudut pandang perlindungan konsumen, pengurangan takaran BBM yang diterima oleh konsumen merupakan pelanggaran terhadap Pasal 4, Pasal 7 dan Pasal 8 Undang-Undang Perlindungan Konsumen, yang diancam dengan sanksi pidana penjara paling lama 5 (lima) tahun atau denda paling banyak Rp. 2 Miliar.

Kemudian, jika melihat ketentuan didalam Undang-Undang Metrologi Legal, kecurangan takaran dilarang melalui Pasal 25 (larangan penggunaan alat ukur yang menyimpan), dan Pasal 30 (larangan memperdagangkan produk yang tidak sesuai dengan takaran). Sanksi terhadap ketentuan tersebut, sebagaimana diatur dalam Pasal 32 ayat (1) dan ayat (2), berupa ancaman pidana masing-masing paling lama 1 tahun penjara atau denda Rp 1 Juta; dan 6 bulan penjara atau denda Rp. 500 ribu.

Penyelesaian sengketa di pengadilan memiliki kekurangan dan kendala seperti penyelesaian sangketa yang dilakukan melalui jalur peradilan sangat lambat, dikarenakan banyaknya perkara perkara yang menumpuk, biaya perkara yang mahal dan juga menurut mereka putusan yang diberikan oleh pengadilan terkadang dianggap tidak menyelesaikan permasalahan semakin rumit, karena putusan dari pengadilan secara objektif tidak dapat menciptakan dan/atau memberikan perdamaian terhadap para pihak yang bersangketa sehingga selalu ada salah satu pihak yang harus kalah di dalam sebuah sading pengadilan. 
Perlindungan konsumen diselenggarakan sebagai Usaha bersama berdasarkan asasasas yang relevan dalam pembangunan nasional. Perlindungan konsumen dapat ditelaan dalam perspektif ekonomi $I_{\text {slam }}^{30}$. Perlindungan konsumen pada terkait rekayasa dispensing pumpoleh pelaku Usaha SPBU di Kota Bandung dalam hukum Islam, yaitu ada pada ketentuan larangan praktik penipuan, berbuat curang, dan unsur gharar. Berdasarkan firman Allah SWT dalam Q.S. Al-Muthaffifin ayat 1-6:

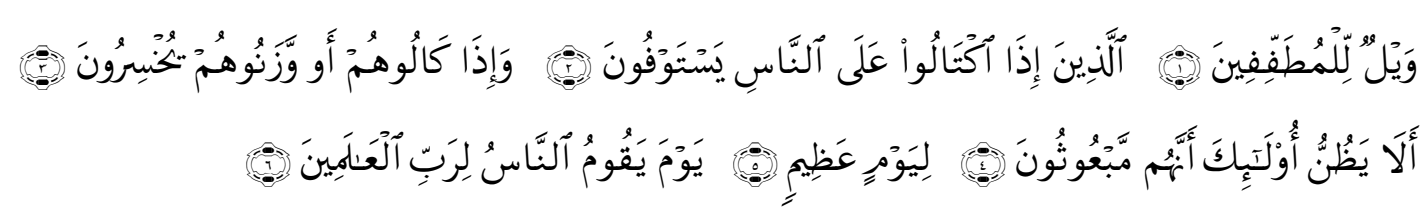

"kecelakaan besarlah bagi orang-orang yang curang. (Yaitu) orang-orang yang apabila menerima takaran dari orang lain mereka minta dipenuhi. Dan apabila mereka menakar atau menimbang untuk orang lain, mereka mengurangi. Tidaklah orang-orang itu menyangka, bahwa Sesungguhnya mereka akan dibangkitkan. Pada suatu hari yang besar. (Yaitu) hari (ketika) manusia berdiri menghadap Tuhan semesta alam."

Rekayasa dispensing pump yang dilakukan oleh pelaku usaha SPBU di Jl. Riau/RE. Martadinata dan Kiaracondong Kota Bandung pada dasarnya tidak sejalan dengan prinsip-prinsip hukum Islam dan asas-asas hukum Islam. Karena seyogyanya perbuatan tersebut merupakan perbuatan yang dilarang baik berdasarkan Firman Allah SWT dalam Al-Quran, maupun oleh Rasulullah SAW dalam Hadist. Rekayasa dispensing pump merupakan tindakan yang bertentangan dengan prinsip-prinsip hukum Islam dan asasasas hukum Islam. Oleh sebab itu sudah seharusnya setiap individu dalam melaksanakan praktik usaha didasarkan dengan kejujuran dan sebisa mungkin menghindari praktik gharar, sehingga pelaku usaha dapat melindungi hak-hak konsumen dalam transaksi jual beli salah satunya yaitu dalam penjualan BBM di SPBU.

\section{Simpulan}

Berdasarkan penyelesaian yang telah dibahas sebelumnya, maka dapat diambil kesimpulan sebagai berikut : Pertama, rekayasa dispensing pump oleh pelaku usaha yang dilakukan oleh pengelola SPBU berdampak pada pencabutan predikat PASTI PAS oleh Pertamina dianggap telah merugikan konsumen, sehingga tanggung jawab pelaku usaha yaitu memberikan ganti rugi sesuai dengan Pasal 19 Undang-undang Perlindungan Konsumen karena telah berbuat wanprestasi. Selanjutnya dalam Hukum Islam penetapan ganti rugi dilakukan apabila unsur-unsur darar atau kerugian pada korban telah terjadi. Kedua, perlindungan hukum bagi konsumen yaitu dalam bentuk preventif dan represif. Preventif dilakukan dengan melakukan pembinaan oleh pemerintah dan Pertamina,

\footnotetext{
${ }^{30}$ Erina Pane, Perlindungan Konsumen dalam Perspektif Undang-undang Perlindungan Konsumen dan Hukum Islam, PRANATA HUKUM yol. 2 No. I, 2007, hlm. 60.
} 
sedangkan represif yaitu dengan adanya penegakan hukum dan/atau penyelesaian sengketa konsumen baik melalui pengadilan maupun di luar pengadilan. Begitu juga pandangan Islam mengenai rekayasa dispensing pump tidak sejalan dengan prinsip dan asas Hukum Islam karena terdapat unsur gharar di dalamnya.

\section{Daftar Pustaka}

A Rahmad Asmuni, Ilmu Figh 3, Jakarta: Direktorat Pemberdayaan Wakaf Direktorat jendral Bimbingan Masyarakat Islam, 2007.

Ahmadi Miru dan Sutarman Yodo, Hukum Perlindungan Konsumen Edisi Revisi, Jakarta: PT. RajaGrafindo Persada, 2015.

Arif Rahman, Penyelesaian Sengketa Konsumen Melalui BPSK Kota Serang, Jurnal Hukum Vol 2 No 1 Juni 2018.

Aulia Muthiah,Tanggung Jawab Pelaku Usaha kepada Konsemen tentang Keamanan Pangan dalam Perspektif Hukum Perlindungan Konsumen, Dialogia Juridicia, Jurnal Hukum Bisnis dan Investasi, Vol.1(1), 05 Mei 2017.

Celina Tri Siwi Kristiyanti, Hukum Perlindungan Konsumen, Jakarta: Cetakan Ketiga, Sinar Grafika Offset, 2011.

Customer satisfaction is everything, Energia edisi September 2018, Coorporate communication sekretaris Perseroan, PT Pertamina.

Erina Pane, Perlindungan Konsumen dalam Perspektif Undang-undang Perlindungan Konsumen dan Hukum Islam, PRANATA HUKUM yol. 2 No. I, 2007.

Frank Zaid, "The Emerging Law on Product Liability and Consumer Product Warranties", Canadian Business Law Journal, 4, 1999.

Inosentius Samsul, Penegakan Hukum Perlindungan Konsumen Melalui Penyelenggaraan Metrologi Legal Dalam Era Otomi Daerah, Jurnal Negara Hukum Vol. 6, No. 2, November 2015.

International Standard Organisation, The Consumer and Standard, Guidance and Principles for Consumer Participation in Standard Development, March, 2003.

Janus Sidabalok, Hukum Konsumen di Indonesia, Bandung: Citra Aditya Bakti, 2010.

John Brich, A.R.,Benefit of Legal Metrology for the Economy and Society, A Study for the International Committee of Legal Metrology, International Committee of Legal Metrology, 2003.

Mahadir, Peranan Pemerintah dalam mengawasi Pasar Perspektif Ekonomi Islam, Jurnal As Salam 2 (1) 2018. 
Maslihati Nur Hidayati, "Analisis tentang alternatif penyelesaian sangketa perlindungan konsumen: Studi tentang efektifitas adan penyelesaian sangketa perlindungan konsumen", Lex jurnalica, vol 5 no 3, Agustus 2008.

Muhammad Nizar, Prinsip Kejujuran dalam perdagangan Versi Islam, Jurnal Istiqro : Jurnal Hukum Islam, Ekonomi dan Bisnis Vol.4 / No.1: 94-102, Januari 2018, ISSN : 25993348 (online) ISSN : $2460-0083$

Nurmasyithahziauddin, Tinjauan Hukum Islam Terhadap Perlindungan Konsumen Pada Transaksi Jual Beli Online,Jurnal Ar raniry, Volume 2, Nomor 1, April 2017

Shidarta, Hukum Perlindungan Konsumen Indonesia, Edisi Revisi, Jakarta: Grasindo, 2004.

Soejono Soekanto dan Sri Mamudji, Penulisan Hukum Normatif Suatu Tinjauan Singkat, Jakarta: PT Raja Grafindo Persada, 2009.

Sutrisni, Moh. Zainol Arief, Pelayanan Pengisian BBM yang tidak memuaskan Di Lingkup Sumenep, Jurnal Jendela Hukum. Volume I Nomor 2 September 2014.

Suyadi, Perlindungan Hukum Konsumen Produk Pangan Olahan yang Mengandung Bahan Rekayasa Genetik, Jurnal Dinamika Hukum Vol. 10 No. 1 Januari 2010.

Tonny Rompis, Kajian Sosiologi hukum tentang Menurunnya Kepercayaan Masyarakat terhadap hukum dan Aparat Penegak Hukum di Sulawesi Utara, Lex Crimen Vol. IV/ No. 8 Oktober 20

Wahyu Sasongko, Ketentuan-Ketentuan Pokok Hukum Perlindungan Konsumen, Bandar Lampung:Penerbit Universitas Lampung, 2007

Yudha Hadian Nur dan Dwi Wahyuniarti Prabowo,Penerapan Prinsip Tanggung Jawab Mutlak Dalam Rangka Perlindungan Konsumen, Jurnal Litbang Perdagangan, Vol. 5 No. 2, Desember 2011.

Yuni Harlina,Hellen Lastfitriani, Kajian Hukum Islam Tentang Wanprestasi Pada Konsumen Yang Tidak Menerima Sertifikat Kepemilikan Pembelian Rumah, Jurnal Hukum Islam, Vol XVII No. 1 juni 2017.

Yusuf Al-Qardhawi, Bunga Bank Haram, Jakarta: Akbar Media Eka Sarana, 2003.

http://jabar.tribunnews.com/2018/10/21/kecurangan-di-dua-spbu-di-bandungmanipulasi-display-meteran-bensin-hingga-buat-konsumen-rugi di akses 5 Februari 2019 pukul 10:30 WIB.

Hasil Wawancara dengan Irawan selaku Pengawas SPBU 34-40133 Riau Kota Bandung pada hari Kamis 11 Juli 2019.

Hasil Wawancara dengan Muhammad Subhan, Marketing di PT. Pertamina Retail Jakarta pada tanggal 28 Juli 2019. 
258 | Asy-Syari'ah Vol. 22 No.1, Juni 2020

Hasil Wawancara dengan Wawuhan Dagis, Marketing di PT. Pertamina Retail Jakarta pada tanggal 23 Juli 2019. 
Asy-Syari'ah (P-ISSN: 2086-9029 E-ISSN: 2654-5675) is a periodical scientific journal that publishes various results of studies and research, literature review, and other scientific works whose scope covers the field of Islamic law/sharia, law and society in monodisciplinary, interdisciplinary, and multidisciplinary manners. The journal aims to expand and create innovative concepts, theories, paradigms, perspectives and methodologies in the above said scope. The Journal is published twice a year (june and december) by Faculty of Shariah and Law, Sunan Gunung Djati State Islamic University Bandung in collaboration with Asosiasi Sarjana Syariah Indonesia (ASSYI).

\section{EDITORIAL OFFICE:}

Fakultas Syariah dan Hukum UIN Sunan Gunung Djati Bandung J1. Raya A.H. Nasution No. 105 Cibiru Kota Bandung, 40614

Tlp/Fax: +022-7802278 Faks. 022-7802278

Website http://journal.uinsgd.ac.id/index.php/asy-syariah/index

E-mail: Jurnalasy-syariah@uinsgd.ac.id 